\title{
PRODUCTIVITY AND QUALITY OF QUINOA YIELD (CHENOPODIUM QUINOA, WILLD) AS AFFECTED BY PLANTING DATE AND PLANT SPACINGS
}

\author{
S.R. Nagib*, A.M.O Gahory ${ }^{* *}$ and A.A Hassan ${ }^{* * *}$ \\ * Agronomy Department, Faculty of Agriculture, Minia University, Minia, Egypt \\ ** Horticultural Department, Faculty of Agriculture, Aswan University, Aswan, Egypt \\ *** Horticultural Department, Faculty of Agriculture, Minia University, Minia, Egypt
}

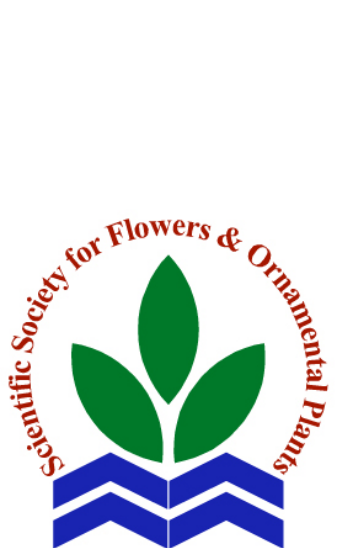

Scientific J. Flowers \& Ornamental Plants, 7(4):541-548 (2020).

Received: $15 / 11 / 2020$ Accepted: $15 / 12 / 2020$
ABSTRACT: A field experiment was conducted at the nursery of ornamental plants, Faculty of Agriculture, Minia University during $2018 / 2019$ and 2019/2020 seasons to study the effect of three planting dates (November $1^{\text {st }}$, November $15^{\text {th }}$ and December $1^{\text {st }}$ ) and three plant spacings $(10,15$ and $20 \mathrm{~cm})$ on growth, yield and chemical composition of quinoa plants to obtain the best agricultural transactions under the conditions of Central Egypt. The results showed significant effects of planting dates on all the studied traits, except for plant height, weight of 1000 seeds and protein $\%$ in both seasons, with the planting date of November $15^{\text {th }}$ being the best date. The effect of plant spacing was significant for all studied characters, except for weight of 1000 seeds and protein $\%$ in the first season. Planting quinoa seeds at $15 \mathrm{~cm}$. was superior to the other spacings in most cases. The interaction between planting dates and plant spacing between plants was insignificant except for number of panicles/plant and yield of seeds/plant $(\mathrm{g})$ in both seasons and the weight of 1000 seed $(\mathrm{g})$ and seed yield/fed (ton) in the second season. Therefore, it is recommended to cultivate the quinoa on November $15^{\text {th }}$ at a distance of $15 \mathrm{~cm}$ apart under the conditions of Central Egypt because it gave the best values for economic characteristics.

Key words: Quinoa, planting dates, planting spacings and protein $\%$.

\section{INTRODUCTION}

Quinoa (Chenopodium quinoa, Willd) plants are belonging to Family Chenopodiaceae. Quinoa is a stress-tolerant plant, cultivated in Andes, Peru, Bolivia, Chile, Ecuador, Colombia and Argentina. Its grains have high protein content with abundance of essential amino acids, wide range of vitamins, especially vit. E, minerals and saponin and it is a promising worldwide plant for human consumption, nutrition and medical industries (Vega-Galvez et al., 2010, Bilalis et al., 2012 and Ning et al., 2020).

Optimum planting date and plant spacing had positive effects on growth, yield and chemical composition of different plant species as emphasized by many authors Thalji and Shalaldeh (2006) on faba bean, Sudeep et al. (2006) and Badran et al. (2007) on fennel and Sajjad et al (2014) on quinoa. However, Bhargava et al. (2007) and Sief et al. (2015) found that the best growth and yield of quinoa was obtained due to $25 \mathrm{~cm}$ spacing and 15 November sowing date, while late sowing date (during December $1^{\text {st }}$ ) gave the lowest yield regardless of plant spacings $(10,20$ and $25 \mathrm{~cm})$, as well as, Sayed et al. (2018) reported that sowing dates affected the growth and productivity due to differences in temperature, precipitation and radiation over the year. The highest seed yield and dry matter yield were obtained for quinoa sown in early date. 
The main objective of this study was to describe the relationship of quinoa productivity and quality response to planting dates, with emphasis on the management effects of planting spaces under environmental condition of Minia Governorate, Egypt.

\section{MATERIALS AND METHODS}

Two field experiments were conducted during both seasons of 2018/2019 and $2019 / 2020$ at nursery of ornamental plants, Faculty of Agriculture, Minia University.

The experiment was arranged in spiltplot design with three replicates. The main plots (A) included three planting dates (November $1^{\text {st }}, 15^{\text {th }}$ and December $1^{\text {st }}$ ). However, spacing distances between plants $(10,15$ and $20 \mathrm{~cm})$ were arranged in the subplots (B). Quinoa seeds variety Denish KVL 3704 were supplied from the Royal Faculty of Agriculture, Copenhagen. Each plot area was $12 \mathrm{~m}^{2}$ consisting of 4 rows with $5 \mathrm{~m}$ long, and spacing was $0.6 \mathrm{~m}$ between rows, and both sides of the row were cultivated by seeds at a depth of $3 \mathrm{~cm}$ in hills (after 3 weeks, the plants were thinned to two plants/hill). Calcium super phosphate $(15.5 \%$ $\mathrm{P}_{2} \mathrm{O}_{5}$ ) was applied to the soil at the rate of $150 \mathrm{~kg} / \mathrm{fed}$ during land preparation. Ammonium nitrate $(33.5 \% \mathrm{~N})$ and potassium sulphate $\left(48 \% \mathrm{~K}_{2} \mathrm{O}\right)$ respectively were added after thinning in two doses, one-month interval.

All agricultural practices were applied as commonly used for growing quinoa in the marginal soil agriculture in the two growth seasons. The physical and chemical properties of the experimental soil in both seasons are shown in Table (1) according to Page et al. (1982).

\section{Data recorded:}

At harvest, ten quinoa plants from each plot were chosen randomly to estimate the following characters, plant height $(\mathrm{cm})$, number of panicles/plant, yield of seeds/plant (g) and per fed $(\mathrm{kg})$, dry weight of foliage yield (ton/fed), 1000 seeds weight (g) and protein percentage according to Page et al. (1982), as well as, saponin (\%) according to San Martun and Briones (2000).

\section{Statistical analysis:}

Data of the two seasons were subjected to the statistical analysis of variance (ANOVA) for the split-plot design with three replications by means of MSTAT-C (1986) computer software package according to Gomez and Gomez (1984). Least significant differences (LSD) test was used to compare means among treatments at 5\% level of probability.

Table 1. Physical and chemical properties of the experimental soil.

\begin{tabular}{|c|c|c|c|c|c|c|}
\hline Soil chemical & Values & \multicolumn{2}{|c|}{ Soil chemical properties } & Values & Soil physical properties & Values \\
\hline pH (1:2.5 water) & 7.70 & \multicolumn{2}{|l|}{ Total P $\left(\mathrm{g} \mathrm{kg}^{-1}\right)$} & 0.56 & F.C. $\%$ & 42.45 \\
\hline $\mathrm{CaCO}_{3}\left(\mathrm{~g} \mathrm{~kg}^{-1}\right)$ & 17.90 & \multicolumn{2}{|l|}{ Available $P\left(\mathrm{mg} \mathrm{kg}^{-1}\right)$} & 13.11 & PWP \% & 13.78 \\
\hline CEC $\left(\right.$ cmol $\left._{\mathrm{c}} \mathrm{kg}^{-1}\right)$ & 37.87 & \multicolumn{2}{|l|}{ Total K ( $\left.\mathrm{g} \mathrm{kg}^{-1}\right)$} & 4.37 & WHC \% & 48.76 \\
\hline $\operatorname{EC~}\left(\mathrm{dS} \mathrm{m}^{-1}\right.$ at $\left.25^{\circ} \mathrm{C}\right)$ & 1.35 & \multicolumn{2}{|c|}{ Exch. $\mathrm{K}^{+}\left(\mathrm{mg} 100 \mathrm{~g}^{-1}\right.$ soil $)$} & 2.85 & A.V. (F.C.- PWP) \% & 28.67 \\
\hline$O M\left(\mathrm{~g} \mathrm{~kg}^{-1}\right)$ & 28.61 & \multicolumn{2}{|c|}{ Exch. Ca ${ }^{++}\left(m g ~ 100 g^{-1}\right.$ soil $)$} & 31.12 & A.V. (WHC-PWP) \% & 34.98 \\
\hline Total N ( g kg $\left.^{-1}\right)$ & 1.29 & \multicolumn{2}{|c|}{ Exch. $\mathrm{Mg}^{++}\left(\mathrm{mg} 100 \mathrm{~g}^{-1}\right.$ soil $)$} & 8.77 & Bulk density (BD) $\mathrm{g} \mathrm{cm}^{-3}$ & 1.31 \\
\hline Total $\mathrm{C} / \mathrm{N}$ ratio & 22.17 & \multicolumn{2}{|c|}{ Exch. $\mathrm{Na}^{+}\left(\mathrm{mg} 100 \mathrm{~g}^{-1}\right.$ soil $)$} & 2.52 & Particle density (PD) $\mathrm{g} \mathrm{cm}^{-3}$ & 2.22 \\
\hline $\operatorname{SOC}\left(\mathrm{g} \mathrm{kg}^{-1}\right)$ & 18.48 & DTPA Ext. $\left(\mathrm{mg} \mathrm{kg}^{-1}\right)$ & $\mathbf{F e}$ & 8.23 & Sand \% & 28.90 \\
\hline Organic $\mathbf{N}\left(\mathrm{g} \mathrm{kg}^{-1}\right)$ & 0.76 & & $\mathbf{C u}$ & 2.01 & Silt \% & 32.80 \\
\hline Organic $\mathrm{C} / \mathrm{N}$ ratio & 24.31 & & $\mathbf{Z n}$ & 2.87 & Clay \% & 38.30 \\
\hline Mineral N (mg kg $\left.{ }^{-1}\right)$ & 58.46 & & Mn & 8.11 & Soil texture & Clayey loam \\
\hline
\end{tabular}




\section{RESULTS}

\section{Plant height:}

Data presented in Table (2) showed that, no significant differences were detected between planting date treatments (November $1^{\text {st }}, 15^{\text {th }}$ and December $\left.1^{\text {st }}\right)$ in both seasons.

Plant height of quinoa was gradually increased by the gradual decrease in plant spaces (from 20,15 up to $10 \mathrm{~cm}$ ). The trend was evident in the two growing seasons.

Planting space at $10 \mathrm{~cm}$ between hills (140.000 plants/fed) gave the tallest plants of (129.9 and $151.1 \mathrm{~cm}$ ) in the first and second seasons, respectively, while, the shortest plants of $(107.2 \mathrm{~cm}$ in the first season and $118.5 \mathrm{~cm}$ in the second season) were recorded with planting space of $20 \mathrm{~cm}$ (70.000 plants/fed). These results are in harmony with those obtained by Sief et al. (2015), Sayed et al. (2018) and Ning et al. (2020) on quinoa plants.

Plant height was significantly affected as influenced by planting date and planting space interaction in both seasons as shown in Table (2). The tallest plants of 130.1 and $150.1 \mathrm{~cm}$ were recorded for the narrowest distance $(10 \mathrm{~cm})$ and first planting date Nov $1^{\text {st }}$. in both seasons, respectively.

\section{Number of panicles/plant:}

Data presented in Table (2) indicated that there were significant differences among planting dates for number of panicles/plant in both seasons. The highest number of panicles/plant (15.2 and 16.2 in the first and second seasons, respectively) was performed from the middle planting date

Table 2. Effect of planting date, planting spacing and their interaction on plant height (cm), number of panicles/plant and yield of seeds/plant of quinoa plants during the first and second seasons.

\begin{tabular}{|c|c|c|c|c|c|c|c|c|}
\hline \multirow{3}{*}{$\begin{array}{l}\text { Plant spacings } \\
\text { (B) }\end{array}$} & \multicolumn{8}{|c|}{ Planting dates (A) } \\
\hline & \multicolumn{4}{|c|}{$1^{\text {st }}$ season $(2018 / 2019)$} & \multicolumn{4}{|c|}{$2^{\text {nd }} \operatorname{season}(2019 / 2020)$} \\
\hline & $1^{\text {st }}$ Nov. & $15^{\text {th }}$ Nov. & $1^{\text {st }}$ Dec. & Mean (B) & $1^{\text {st }}$ Nov. & $15^{\text {th }}$ Nov. & $1^{\text {st }}$ Dec. & Mean (B) \\
\hline & \multicolumn{8}{|c|}{ Plant height (cm) } \\
\hline $10 \mathrm{~cm}$ & 130.1 & 130.3 & 129.1 & 129.9 & 150.1 & 147.8 & 131.4 & 151.1 \\
\hline $15 \mathrm{~cm}$ & 121.2 & 114.8 & 114.3 & 116.8 & 123.6 & 129.6 & 121.3 & 124.9 \\
\hline $20 \mathrm{~cm}$ & 109.3 & 107.6 & 104.3 & 107.1 & 117.4 & 123.1 & 114.9 & 118.5 \\
\hline Mean (A) & 120.2 & 117.6 & 116.0 & & 131.7 & 133.3 & 124.3 & \\
\hline \multirow[t]{2}{*}{ L.S.D. at $5 \%$} & A: N.S & \multicolumn{2}{|c|}{ B: 6.3} & AB: 10.9 & A: N.S & \multicolumn{2}{|c|}{ B: 7.4} & AB: 12.8 \\
\hline & \multicolumn{8}{|c|}{ Number of panicles/plant } \\
\hline $10 \mathrm{~cm}$ & 5.5 & 10.7 & 10.3 & 8.9 & 3.9 & 11.6 & 11.4 & 9.6 \\
\hline $15 \mathrm{~cm}$ & 13.6 & 14.8 & 14.6 & 14.3 & 14.7 & 16.0 & 15.8 & 15.5 \\
\hline $20 \mathrm{~cm}$ & 18.4 & 20.2 & 18.7 & 19.1 & 19.9 & 21.8 & 20.2 & 20.4 \\
\hline Mean (A) & 12.5 & 15.2 & 14.6 & & 13.3 & 16.2 & 15.8 & \\
\hline \multirow[t]{2}{*}{ L.S.D. at $5 \%$} & A: 0.3 & \multicolumn{2}{|c|}{ B: 1.3} & AB: 2.25 & A: 0.4 & \multicolumn{2}{|c|}{ B: 1.8} & AB: 3.1 \\
\hline & \multicolumn{8}{|c|}{ Yield of seeds/plant (g) } \\
\hline $10 \mathrm{~cm}$ & 1.1 & 13.9 & 7.0 & 7.3 & 1.6 & 7.8 & 8.4 & 6.6 \\
\hline $15 \mathrm{~cm}$ & 7.1 & 7.4 & 10.6 & 8.4 & 7.6 & 17.6 & 12.5 & 12.6 \\
\hline $20 \mathrm{~cm}$ & 11.9 & 14.6 & 11.7 & 12.7 & 12.3 & 21.1 & 18.1 & 17.2 \\
\hline Mean (A) & 6.7 & 12.0 & 9.8 & & 7.2 & 16.2 & 13.0 & \\
\hline L.S.D. at $5 \%$ & A: 1.5 & & & AB: 1.7 & A: 2.1 & B: & & AB: 2.6 \\
\hline
\end{tabular}




\section{S.R. Nagib et al.}

(November $\left.15^{\text {th }}\right)$. On the other hand, the lowest number of panicles/plant (12.5 and 13.3 in the first and second seasons, respectively) was recorded from planting date of November $1^{\text {st }}$.

The suitable planting date caused an increase in yield components as emphasized by Mohan et al. (2001) and Ayub et al. (2008) on fennel, Botros (2013) on caraway plants, Sajjad et al. (2014) and Ning et al. (2020) on quinoa.

Data presented in Table (2) cleared that number of panicles/plant was gradually increased in both seasons, according to the gradual increase in planting spaces with significant differences being obtained among the different space treatments. So, the widest space $(20 \mathrm{~cm})$ produced the highest number of panicles/plant (19.1 and 20.4 in the first and second seasons, respectively).

The increase in number of panicles/plant due to increasing plant spaces was emphasized by Badran and Hafez (2002) on Nigella sativa, Badran et al. (2003) on anise, Badran et al. (2007) on fennel and Bhargava et al. (2007) on quinoa.

The interaction between planting date and plant space treatments was significant for number of panicles/plant in both seasons as shown in Table (2). The highest values (20.2 and 21.8 in first and second seasons, respectively) were obtained from the second planting date (November $15^{\text {th }}$ ) in combination with the widest planting space $(20 \mathrm{~cm})$.

\section{Yield of seeds/plant:}

Regarding planting date presented in Table (2) indicated significant differences in plant seeds yield, respocets planting dates in both seasons. The middle of November planting date produced the heaviest weight of seeds/plant as recorded $12.0 \mathrm{~g}$ in the first season and 16.2 in the second one. Similar results were obtained by Aaron et al. (2006) on winter triticale plant, Botros (2013) on caraway plants, Sajjad et al. (2014) and Ning et al. (2020) on quinoa.
Seed yield of quinoa plants was significantly increasing due to increasing plant space in both seasons as presented in Table (2). The increase in yield of seeds/plant was gradual and parallel to the gradual increase in plant spaces, the heaviest seeds yield being obtained from the widest space $(20 \mathrm{~cm})$. Such superior treatment recorded 12.7 and $17.2 \mathrm{~g}$ in the $1^{\text {st }}$ and $2^{\text {nd }}$ seasons, respectively. These results were found to be in harmony with the findings of Badran et al. (2007) on fennel, Sief et al. (2015), Sayed et al. (2018) and Ning et al. (2020) on quinoa.

The interaction between main and sub plots $(\mathrm{A} \times \mathrm{B})$ treatments was significant for yield of seeds/plant in both seasons. The highest values of 14.6 and $21.1 \mathrm{~g}$ were obtained from second planting date with the widest plant space in both seasons, respectively.

\section{Seed yield/fed:}

Data presented in Table (3) showed that the treatment of November $15^{\text {st }}$ planting date gave significantly the heaviest yield/fed than the first and third planting dates. The present results were in harmony with those obtained by Aaron et al. (2006) on winter triticale plant and Sajjad et al. (2014) on quinoa.

Regarding planting space, data exhibited in Table (3) cleared that there were significant differences between space treatments for seed yield/fed in both seasons. The narrowest space was more effective than the middle and large spaces as gave 2053.3 $\mathrm{kg}$ in the first season and 1848.0 in the second one. Similar results were obtained by Badran et al. (2007) on fennel, Sief et al. (2015), Sayed et al. (2018) and Ning et al. (2020) on quinoa.

The interaction between planting date and planting space treatments was significant for seed yield/fed in both seasons. The best interaction treatment was planting quinoa on November $15^{\text {th }}$ in combination with $10 \mathrm{~cm}$ planting space in both growing seasons as cleared in Table (3). 
Table 3. Effect of planting date, planting spacing and their interaction on seed yield/fed (kg), weight of 1000 seeds (g) and dry weight of foliage (ton) and yield of seeds/plant of quinoa plants during the first and second seasons.

\begin{tabular}{|c|c|c|c|c|c|c|c|c|}
\hline \multirow{3}{*}{$\begin{array}{l}\text { Plant spacings } \\
\text { (B) }\end{array}$} & \multicolumn{8}{|c|}{ Planting dates (A) } \\
\hline & \multicolumn{4}{|c|}{$1^{\text {st }}$ season $(2018 / 2019)$} & \multicolumn{4}{|c|}{$2^{\text {nd }}$ season $(2019 / 2020)$} \\
\hline & $1^{\text {st }}$ Nov. & $15^{\text {th }}$ Nov. & $1^{\text {st }}$ Dec. & Mean (B) & $1^{\text {st }}$ Nov. & $15^{\text {th }}$ Nov. & $1^{\text {st }}$ Dec. & Mean (B) \\
\hline & \multicolumn{8}{|c|}{ Seed yield/fed (kg) } \\
\hline $10 \mathrm{~cm}$ & 308 & 3892 & 1960 & 2053.3 & 448 & 2744 & 2352 & 1848.0 \\
\hline $15 \mathrm{~cm}$ & 994 & 1036 & 1484 & 1171.3 & 1064 & 2464 & 1750 & 1759.3 \\
\hline $20 \mathrm{~cm}$ & 833 & 1022 & 819 & 819.3 & 875 & 1477 & 1267 & 1206.3 \\
\hline Mean (A) & 711.7 & 1983.3 & 1421.0 & & 795.7 & 2228.3 & 1789.7 & \\
\hline \multirow[t]{2}{*}{ L.S.D. at $5 \%$} & A: 78.1 & \multicolumn{2}{|c|}{ B: 55.2} & AB: 95.6 & A: 88.3 & \multicolumn{2}{|c|}{ B: 67.3} & AB: 116.6 \\
\hline & \multicolumn{8}{|c|}{ Weight of 1000 seeds (g) } \\
\hline $10 \mathrm{~cm}$ & 2.28 & 2.17 & 2.16 & 2.20 & 2.18 & 2.16 & 2.14 & 2.16 \\
\hline $15 \mathrm{~cm}$ & 2.70 & 2.23 & 2.12 & 2.18 & 2.24 & 2.19 & 2.15 & 2.19 \\
\hline $20 \mathrm{~cm}$ & 2.13 & 2.16 & 2.16 & 2.16 & 2.25 & 2.19 & 2.16 & 2.20 \\
\hline Mean (A) & 2.21 & 2.19 & 2.15 & & 2.22 & 2.18 & 2.15 & \\
\hline \multirow[t]{2}{*}{ L.S.D. at $5 \%$} & A: 0.05 & \multicolumn{2}{|c|}{ B: N.S } & AB: N.S & A: 0.05 & \multicolumn{2}{|c|}{ B: N.S } & AB: N.S \\
\hline & \multicolumn{8}{|c|}{ Dry weight of foliage (ton) } \\
\hline $10 \mathrm{~cm}$ & 2.3 & 2.2 & 1.9 & 2.1 & 1.9 & 2.4 & 1.7 & 2.0 \\
\hline $15 \mathrm{~cm}$ & 2.0 & 2.1 & 2.0 & 2.0 & 2.3 & 2.5 & 1.8 & 2.2 \\
\hline $20 \mathrm{~cm}$ & 2.1 & 2.0 & 2.1 & 2.1 & 2.3 & 2.2 & 1.8 & 2.1 \\
\hline Mean (A) & 2.1 & 2.1 & 2.0 & & 2.2 & 2.4 & 1.8 & \\
\hline L.S.D. at $5 \%$ & A: N.S & & & AB: N.S & A: 0.1 & B: & & AB: N.S \\
\hline
\end{tabular}

\section{Weight of 1000 seeds:}

Regarding planting date presented in Table (3) showed, significant differences among planting dates for weight of 1000 seeds ( $\mathrm{g}$ ) in both seasons. The heaviest weight of 1000 seeds were obtained from the first date $\left(\right.$ November ${ }^{\text {st }}$ ).

Weight of 1000 seeds was not significantly affected by plant spacing in both seasons. The interaction between treatments was dose not significant in both seasons.

\section{Dry weight of foliage/fed:}

Regarding the effect of planting date on dry weight of foliage, there were significant differences between treatments in the second season only as shown in Table (3). The second planting date (November $15^{\text {th }}$ ) produced the heaviest dry weight of foliage/fed (ton) than either first and third planting dates (November $1^{\text {st }}$ and December $\left.1^{\text {st }}\right)$. Similarly, were the fiend of Hirich et al. (2014) on quinoa.

Each of the effect of plant spacing and interaction between the main and sub plot treatments were not significant for dry weight of foliage/fed, (ton) in both seasons as shown in Table (3).

\section{Protein percentage:}

Data presented in Table (4) indicated that there were significant differences were detected between treatments for planting dates for protein (\%) in both seasons. In the first season, the high percentage of protein was obtained from the first date of November $(10.52 \%)$, while, the third 
Table 4. Effect of planting date, planting spacing and their interaction on Protein (\%) and saponin (\%) of quinoa plants during the first and second seasons.

\begin{tabular}{|c|c|c|c|c|c|c|c|c|}
\hline \multirow{3}{*}{$\begin{array}{l}\text { Plant spacings } \\
\text { (B) }\end{array}$} & \multicolumn{8}{|c|}{ Planting dates (A) } \\
\hline & \multicolumn{4}{|c|}{$1^{\text {st }}$ season $(2018 / 2019)$} & \multicolumn{4}{|c|}{$2^{\text {nd }}$ season $(2019 / 2020)$} \\
\hline & $1^{\text {st }}$ Nov. & $15^{\text {th }}$ Nov. & $1^{\text {st }}$ Dec. & Mean (B) & $1^{\text {st }}$ Nov. & $15^{\text {th }}$ Nov. & $1^{\text {st }}$ Dec. & Mean (B) \\
\hline & \multicolumn{8}{|c|}{ Protein (\%) } \\
\hline $10 \mathrm{~cm}$ & 10.26 & 10.57 & 10.60 & 10.48 & 10.28 & 10.30 & 10.29 & 10.29 \\
\hline $15 \mathrm{~cm}$ & 10.59 & 10.61 & 10.36 & 10.52 & 11.10 & 11.22 & 11.10 & 11.14 \\
\hline $20 \mathrm{~cm}$ & 10.71 & 10.31 & 10.28 & 10.43 & 10.78 & 10.78 & 10.86 & 10.81 \\
\hline Mean (A) & 10.52 & 10.50 & 10.41 & & 10.72 & 10.73 & 10.80 & \\
\hline \multirow[t]{2}{*}{ L.S.D. at $5 \%$} & A: 0.02 & \multicolumn{2}{|c|}{ B: 0.04} & AB: 0.07 & A: 0.01 & \multicolumn{2}{|c|}{ B: 0.04} & AB: 0.07 \\
\hline & \multicolumn{8}{|c|}{ Saponin (\%) } \\
\hline $10 \mathrm{~cm}$ & 0.25 & 0.31 & 0.30 & 0.31 & 0.25 & 0.31 & 0.30 & 0.31 \\
\hline $15 \mathrm{~cm}$ & 0.26 & 0.34 & 0.32 & 0.33 & 0.33 & 0.34 & 0.32 & 0.35 \\
\hline $20 \mathrm{~cm}$ & 0.24 & 0.30 & 0.30 & 0.30 & 0.24 & 0.31 & 0.30 & 0.30 \\
\hline Mean (A) & 0.25 & 0.32 & 0.31 & & 0.27 & 0.32 & 0.31 & \\
\hline L.S.D. at $5 \%$ & A: 0.02 & B: 0 & & AB: 0.03 & A: 0.01 & B: 0 & .04 & AB: 0.07 \\
\hline
\end{tabular}

planting date (December $1^{\text {st }}$ ) recorded the highest protein percentage $(10.80 \%)$ in the second one.

With respect to plant spacing, either 15 $\mathrm{cm}$ in both seasons recorded the highest protein percentage as 10.52 and $11.14 \%$, respectively.

The interaction between the two factors was significant in both seasons with regard to protein percentage in case of planting quinoa in November $1^{\text {th }}$ at $20 \mathrm{~cm}$ spacing in the first season and November $15^{\text {th }}$ at $15 \mathrm{~cm}$ spacing in the second one.

\section{Saponin percentage:}

Data presented in Table (4) showed significant differences were detected between treatments of planting dates in both seasons for saponin percentage. The second date recorded the highest saponin $(\%)$.

The plant spacing had significant differences in saponin percentage with high percentage of 0.32 and 0.35 in the first and second seasons, respectively detected by sowing quinoa plants at $15 \mathrm{~cm}$, respectively.
The interaction between main and sub plot treatments was significant for saponin percentage in both seasons.

\section{DISCUSSION}

The suitable climatic conditions and environments of factors may enhance biosynthesis processes and photosynthesis to obtain good plant which could explain the obtained results (Ayub et al., 2008; Botros, 2013; Hirich et al., 2014, Sajjad et al., 2014 and Ning et al., 2020). As for increase in these traits with increasing plant spacing between quinoa plants might be due to the low below and above ground competition between plants for illumination and nutrients and water.

These results are in accordance with those obtained by Bhargava et al. (2007); Badran et al. (2007) and Sief et al. (2015). There were decreases in grain yield/fed with increasing the distances between plants up to the widest of $15 \mathrm{~cm}$ apart.

\section{CONCLUSION}

It can be concluded that the best growth and yield of quinoa plants were recorded 
from sowing quinoa seeds in the middle of November at $15 \mathrm{~cm}$ apart.

\section{REFERENCES}

Aaron, J.S.; Lance, R.G.; Douglas, L.K.; Philip, M.D.; Matt, L. and Jean-Luc, J. (2006). Planting date effects on winter triticale grain yield and yield components. Crop Ecology, Crop Science Society of America J. Sci., 46:1218-1224.

Ayub, M; Nadeem, M.A.; Tanveer, A.; Tahir, M.; Saqib, M.T.Y. and Nawaz, R. (2008). Effect of different sowing methods and times on the growth and yield of fennel (Foeniculum vulgare, Mill). Pak. J. Bot., 40(1):259-264.

Badran, F.S. and M.H. Hafez (2002). Influence of planting date and plant density on Nigella sativa, L. plants. Proc. the $2^{\text {nd }}$ Conference of Sustainable Agricultural Development, Faculty of Agriculture, Fayoum, Egypt., 8-10 May.

Badran, F.S.; Abdalla, N.M.; Aly, M.K. and Ibrahim, S.M. (2007). Response of fennel plants to seedling rate and partial replacement of mineral NPK by biofertilization treatments. Pro. of the $8^{\text {th }}$ African Crop. Sci. Conf., El-Minia, Egypt, 27-31, Oct., 2007, 8(1):417-422.

Badran, F.S.; Attia, F.A.; Ahmed, E.T. and Soliman, H.A. (2003). Effect of chemical and biological fertilization on growth, yield and oil production of anise (Pimpinella anisum, L.) plants. II-Effect of NP mineral/biofertilization and micronutrient treatments. Proc. EgyptianSyrian $1^{\text {st }}$ Conf., Minia Univ., Dec.

Bhargava, A.; Shukla, S. and Ohri, D. (2007). Effect of sowing dates and row spacing on yield and quality of quinoa (Chenopodium quinoa). Indian J. of Agric. Sci., 77(11):748-751.

Bilalis, D.; Kakabouki, J.; Karkanis, A.; Travols, I.; Triantafyllidis, V. and Hela, D. (2012). Seed and saponin production of organic quinoa (Chenopodium quinoa, Willd.) for different Tillage and fertilization. Not. Bot. Horti. Agrobo., 40(1):42-46.

Botros, W.S.E. (2013). Physiological Studies on Caraway Plants. M.Sc. Thesis, Fac. Agric., Minia Univ., Egypt, 106 p.

Gomez, K.A. and Gomez, A.A. (1984). Statistical Procedure for Agricultural Research. $2^{\text {nd }} E d$, John Wiley and Sons, New York, USA., 657 p.

Hirich, A.; Choukr-Allah, R. and Jacobsen, S.E. (2014). Quinoa in Morocco- Effect of sowing dates on development and yield, J. Agron. Crop Sci., 200:371-377.

Mohan, V.P.; Batra, V.K. and Thakral, K.K. (2001). Response of sowing dates and seed rate on growth and yield of fennel. Haryana J. Hort. Sci., 30(3-4):271-273.

MSTAT-C (1986). A Microcomputer Program for the Design Management and Analysis of Agronomic Research Experiments (version 4.0), Michigan State Univ., U.S.A.

Ning, W.; Fengxin, W.; Clinton, C.S.; Chaobiao, M. and Lifang, Q. (2020). Effects of management practices on quinoa growth seed yield and quality. J. Agronomy, 10:445:1-15.

Page, A.L.; Miller, R.H. and Kenney, D.R. (1982). Methods of Soil Analysis, Part I. Amer. Soc. Agron. Wisconsin, USA., $1159 \mathrm{p}$.

Sajjad, A.; Hassan, M.; Ehsanullah, S.A.A.; Mohsin, T. and Aziz, R. (2014). Growth and development of Chenopodium quinoa genotypes at different sowing dates. J. Agric. Res., 52(4):535-546.

San Martun, R. and Briones, R. (2000). Quality control of commercial quillay (Quillajas aponaria, Molina) extracts by reverse phase HPLC. J. Sci. Food Agric., 80:2063-2068.

Sayed S.E.; Abd El-Samad, E.H.; Hussin, S.A.; Ali, E.A.; Ebrahim, M.; González, J.A.; Mariano, O.; Luis, E.E.; ElBordeny, N.E. and Abdel-Ati, A.A. (2018). Quinoa in Egypt - plant density 


\section{S.R. Nagib et al.}

effects on seed yield and nutritional quality in marginal regions. Mid. East $\mathrm{J}$. of Appl. Sci., 8(2):515-522.

Sief, A.S.; El-Deepah, H.R.A.; Kamel, A.S.M. and Jacline, F.I. (2015). Effect of various inter and intra spaces on the yield and quality of quinoa (Chenopodium quinoa Willd.). J. Plant Prod., Mansoura. Univ., 6(3):371-383.

Sudeep, S.; Buttar, G.S. and Singh, S.P. (2006). Growth, yield and heat unit requirement of fennel (Foeniculum vulgare) as influenced by date of sowing and row spacings under semi-arid region of Punjab. J. of Medicinal and Aromatic Plant Sci., 28(3):363-365.
Thalji, T. and Shalaldeh, G. (2006). Effect of date of sowing on faba bean (Vicia faba, L.) nodulation and performance under semi-arid conditions. World J. of Agri. Sci., 2(4):477-482.

Vega-Galvez, A.; Miranda, M.; Vergara, J.; Uribe, E.; Puente, L. and Martinez, E.A. (2010). Nutrition facts and functional potential of quinoa (Chenopodium quinoa, Willd.) and ancient Andean grain: a review. J. of the Sci. of Food and Agriculture, 90:2541-2547.

$$
\begin{aligned}
& \text { إنتاجية وجودة محصول الكنوا وتأثر ها بمواعيد ومسافات الزراعة }
\end{aligned}
$$

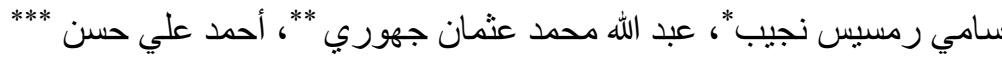

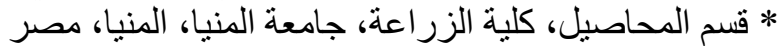

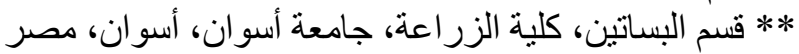

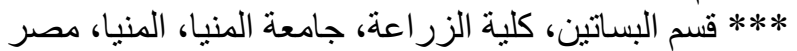

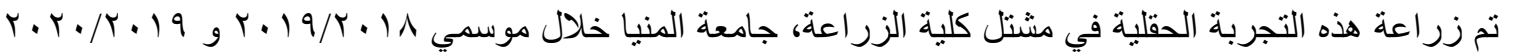

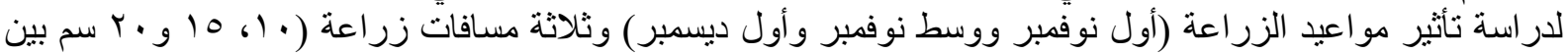

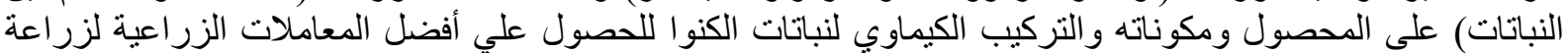

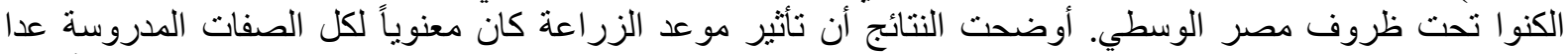

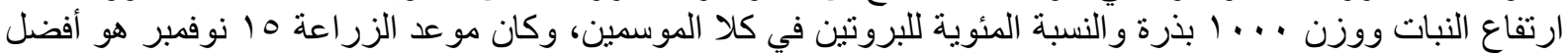

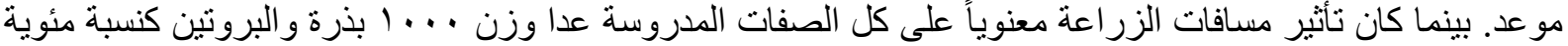

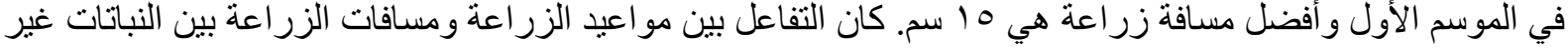

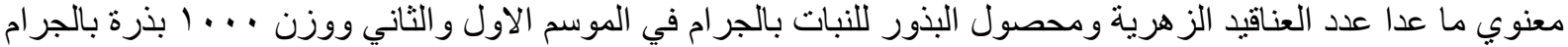

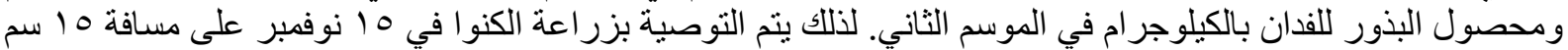
تحت ظروف مصر الوسطى لانها أعطت أفضل القيم للصفات الاقتصادية. 